\title{
PENGEMBANGAN LKPD BERBASIS \\ PROBLEM BASED LEARNING UNTUK MELATIH \\ KEMAMPUAN KONEKSI MATEMATIS PESERTA DIDIK KELAS XI
}

\author{
${ }^{1)}$ Tito Nurdiyanto, ${ }^{2)}$ Inda Rafida, ${ }^{3)}$ Aulia Nuhadila, ${ }^{4)}$ Sesi Winarni \\ ${ }^{1)}$ SMA Negeri 2 Tungkal Jaya, Sumber Sari, Musi Banyuasin, Kabupaten Musi Banyuasin, \\ Sumatera Selatan, Indonesia \\ ${ }^{2)}$ SMA Negeri 2 Palembang, Jl. Puncak Sekuning No.84, Lorok Pakjo, Kec. Ilir Bar. I, Kota \\ Palembang, Sumatera Selatan, Indonesia \\ ${ }^{3)}$ MAN 1 Pesawaran, Gn. Sugih, Kedondong, Kabupaten Pesawaran, Lampung, Indonesia \\ ${ }^{4)}$ Pondok Pesantren Darul Qur'an Wal Hadist, Jl. Tuanku Imam Bonjol, Kota Baru Selatan, \\ Martapura, Kota Baru Sel., Martapura, Kabupaten Ogan Komering Ulu Timur, Sumatera \\ Selatan, Indonesia
}

titonurdiyanto_tnk@yahoo.co.id, rafidainda@yaho.com, aulianuhadila@gmail.com, ssessiiww@gmail.com

\begin{abstract}
This study was intended to produce a learner worksheet based on problem with valid and practical, and to determine the potential effects on mathematical connections ability in derivative material. This research type is development with formative research. The subjects of this research were 36 students of class XI MIPA 1 SMAN 2 Palembang. The techniques that used in data collection are interviews, document analysis, and test. Based on the result of document and data analysis could be concluded that this research produced worksheet based on problem based learning in derivative material that valid and practical, and the worksheet that had been developed had a potential effect on students mathematical connections ability in derivative material. Therefore worksheet from this research that had been developed can be used by the students.
\end{abstract}

Keywords: Development, Student Worksheet, Problem Based Learning, Mathematical Connection Ability

\begin{abstract}
Abstrak
Penelitian ini bertujuan untuk menghasilkan lembar kerja peserta didik (LKPD) berbasis problem based learning yang valid dan praktis, serta untuk mengetahui efek potensial terhadap kemampuan koneksi matematis peserta didik pada materi turunan. Jenis penelitian yang digunakan adalah penelitian pengembangan atau development research tipe formative research. Subjek penelitiannya adalah peserta didik kelas XI MIPA 1 SMAN 2 Palembang sebanyak 36 orang peserta didik. Teknik pengumpulan data yang digunakan adalah wawancara, analisis dokumen dan tes. Hasil analisis wawancara, dokumen dan tes dapat disimpulkan bahwa penelitian ini menghasilkan lembar kerja peserta didik (LKPD) materi turunan berbasis problem based learning yang valid dan praktis, serta memiliki efek potensial terhadap kemampuan koneksi matematis peserta didik pada materi turunan. Oleh karena itu, LKPD yang telah dikembangkan ini dapat digunakan oleh peserta didik.
\end{abstract}

Kata Kunci : Pengembangan, Lembar Kerja Peserta Didik, Problem Based Learning, Kemampuan Koneksi Matematis

Cara Menulis Sitasi: Nurdiyanto, T., Rafida, I., Nuhadila, A., Winarni, S. (2020). Pengembangan LKPD Berbasis Problem Based Learning pada Materi Turunan untuk Melatih Kemampuan Koneksi Matematis Peserta Didik Kelas X. Jurnal Edukasi dan Sains Matematika (JES-MAT), 6 (1), 37 - 54. 


\section{PENDAHULUAN}

Turunan fungsi aljabar merupakan materi penting yang harus dipelajari oleh peserta didik, baik program MIPA maupun IPS. Ditinjau dari Kurikulum 2013 pada mata pelajaran Matematika Wajib, materi turunan fungsi aljabar ada pada jenjang Kelas XI (Kemendikbud, 2017). Turunan fungsi aljabar juga banyak digunakan di bidang eksak maupun sosial, seperti menghitung kepadatan kawat, laju pertumbuhan organisme, pemisahan molekul, biaya marginal, biaya total, dan biaya total penerimaan (Burhanuddin \& Utami, 2017). Dalam Ujian Nasional pun terdapat aplikasi turunan yang disajikan dalam bentuk penyajian masalah yang berkaitan dengan materi lainnya.

Namun kenyataannya, turunan fungsi aljabar menjadi materi yang masih sulit dikuasai oleh sebagian besar peserta didik. Jika dihadapkan dengan soal penyajian masalah yang berkaitan dengan materi turunan fungsi aljabar, peserta didik akan kesulitan menerjemahkan bacaan soal menjadi kalimat matematika dan mengaitkan permasalahan dengan konsep lain yang terkait (Faudziah, Nurainah, Nuryatin, Maryanasari, \& Hidayat, 2019; Asih, Rosita, \& Tonah, 2018). Didukung dengan hasil penelitian Apriliyanto (2019) menunjukkan bahwa terdapat beberapa kesalahan yang dilakukan peserta didik dalam menyelesaikan permasalahan turunan fungsi aljabar. Kesalahan tersebut adalah kesalahan dalam memahami masalah sebesar 7,5\%, kesalahan dalam tahap merencanakan penyelesaian sebesar $12,5 \%$, dan kesalahan dalam menyelesaikan masalah sebesar 55\%. Dari uraian-uraian di atas, jelas koneksi matematis peserta didik materi turunan fungsi aljabar masih rendah.
Padahal koneksi matematis adalah aspek yang sangat penting dimiliki oleh peserta didik. Hal ini ditinjau dalam Kurikulum 2013 revisi pada Kompetensi Lulusan dalam dimensi pengetahuan, yaitu kemampuan peserta didik untuk mengaitkan pengetahuan tentang teknologi, seni, budaya, dan humaniora dalam konteks diri sendiri, keluarga, sekolah, masyarakat, dan lingkungan alam sekitar, bangsa, negara, serta kawasan regional (Kemendikbud, 2016). Namun, sebagian besar peserta didik masih mempelajari matematika dengan terpisah, tidak mengerti bagaimana keterkaitan antar konsep dalam matematika maupun di luar konteks matematika (Asih, Rosita, \& Tonah, 2018). Hal ini yang membuat mereka kesulitan dalam memahami suatu permasalahan dalam matematika.

Kemampuan koneksi matematis sendiri adalah kemampuan mengaitkan antar topik matematika, mengaitkan matematika dengan disiplin ilmu lain, dan mengaitkan matematika dengan kehidupan sehari hari. (Fajar, Wahyuni, \& Santi, 2019; Astuti, Hartono, Bunayati, \& Indaryanti, 2017; Lestari \& Yudhanegara, 2015). Dalam penelitian ini, untuk membantu peserta didik mengembangkan kemampuan koneksi matematis, peneliti mengembangkan Lembar Kerja Peserta Didik (LKPD) berbasis Problem Based Learning (PBL) materi turunan fungsi aljabar.

PBL merupakan model pembelajaran yang berorientasi pada masalah yang dirancang untuk mendukung peserta didik secara aktif memperdalam pengetahuannya dan melihat keterkaitan antar konsep saat memecahkan masalah (Septian \& Komala, 2019; Atiningsih, 
2018; Herawati, 2017; Lestari, Saputri, \& Prihartini, 2016). Kemampuan mengaitkan antar konsep matematika dalam memecahkan masalah akan terjadi pada struktur kognitif (Nurdiyanto, Hartono, \& Indaryanti, 2019; Rustina \& Anisa, 2018). Ketika peserta didik mengungkapkan ide, gagasan terhadap permasalahan yang diberikan dengan mengaitkan konsepkonsep sebelumnya dengan pengetahuan baru yang dihadapi akan menjadikan proses pembelajaran lebih bermakna untuk mendukung penyelesaian masalah tersebut (Nurdiyanto, Rafida, \& Zulkardi, 2019). Dengan PBL, peserta didik yang melihat keterkaitan antar konsep-konsep dalam matematika dan keterkaitan matematika dengan ilmu disiplin yang lain mempunyai pengetahuan yang luas untuk menyelesaikan permasalahan yang dihadapi.

Hasil penelitian Zulfah, Fauzan, \& Armiati (2018) tentang pengembangan LKPD berbasis PBL untuk mengetahui kemampuan pemecahan masalah. LKPD tersebut dapat membantu peserta didik dalam menyelesaikan permasalahan. Dalam proses menjawab pertanyaan di LKPD tersebut, peserta didik menerjemahkan permasalahan ke dalam bentuk matematika, membuat variabel, mengaitkan konsep matematika, membuat model matematika untuk menyelesaikan permasalahan tersebut. Penelitian oleh Prisiska, Hapizah, \& Yusuf (2017) memiliki efek potensial terhadap hasil belajar peserta didik. Dalam LKPD, peserta didik dituntut untuk mengembangkan kemampuan berfikir peserta didik dalam menyelesaikan permasalahan.

Dari hasil penelitian-penelitian tersebut, dapat dilihat bahwa proses atau langkah-langkah PBL itu sendiri sangat penting untuk dapat mengembangkan kemampuan matematika peserta didik sesuai dengan tujuan pembelajaran.

Sehubungan dengan latas belakang di atas, peneliti tertarik melakukan penelitian dengan judul "Pengembangan LKPD Berbasis Problem Based Learning untuk Melatih Kemampuan Koneksi Matematis Peserta Didik Kelas XI"

\section{LANDASAN/KAJIAN TEORI Model Problem Based Learning (PBL) \\ Problem Based Learning (PBL)} merupakan model pembelajaran yang menghadapkan peserta didik pada suatu masalah sejak awal, kemudian diikuti oleh aktivitas proses pencarian informasi yang berpusat pada siswa (Suprihatiningrum, 2014). Pada aspek filosofi, PBL berpusat pada peserta didik yang dihadapkan pada suatu permasalahan. PBL bertujuan agar peserta didik mampu memperoleh dan mengkonstruksi pengetahuan secara efisien, kontekstual, dan terintegrasi.

Senada dengan Lestari \& Yudhanegara (2015), PBL adalah model pembelajaran yang menghadapkan peserta didik pada suatu masalah sehingga peserta didik dapat mengembangkan kemampuan berpikir tingkat tinggi dan keterampilan penyelesaian masalah, serta memperoleh pengetahuan baru terkait dengan permasalahan tersebut. Menurut Rusman (2016:229) menyatakan bahwa model PBL adalah salah satu model pembelajaran yang memfasilitasi berkembangkannya keterampilan berfikir peserta didik (penalaran, komunikasi, dan koneksi) dalam memecahkan masalah. Model PBL menjadi inovasi pembelajaran karena dalam proses pembelajarannya, kemampuan peserta didik dioptimalkan melalui proses kerja kelompok atau tim yang sistematis, 
sehingga peserta didik dapat membudayakan, mengasah, dan mengembangkan kemampuan befikirnya secara berkesibambungan.

Berdasarkan penjelasan di atas, dapat disimpulkan bahwa PBL adalah model pembelajaran dimana peserta didik dihadapkan pada suatu masalah nyata, sehingga peserta didik berperan aktif dalam kegiatan belajar dan mampu menyelesaikan masalah dengan tujuan peserta didik memperoleh dan mengembangkan pengetahuannya.

Menurut Trianto (2017:93), PBL memiliki beberapa karakteristik, yaitu pengajuan pertanyaan atau masalah, berfokus pada keterkaitan antardisiplin, penyelidikan autentik, menghasilkan produk dan memaparkannya, serta kolaborasi. Sintak dalam PBL adalah (1) orientasi peserta didik pada masalah, (2) mengorganisasikan peserta didik untuk belajar, membimbing penyelidikan individu dan kelompok, (4) mengembangkan dan menyajikan hasil karya, serta (5) menganalisis dan mengevaluasi proses pemecahan masalah (Trianto, 2017:98). Dalam penelitian ini langkah-langkah PBL yang digunakan adalah (1) orientasi peserta didik pada masalah (memahami permasalahan), (2) mengorganisasikan peserta didik pada masalah (mengidentifikasi permasalahan), membimbing penyelidikan individu dan kelompok (merancang rencana penyelesaian), (4) mengembangkan dan menyajikan hasil karya (mengembangkan rencana menyelesaikan) serta menganalisis dan mengevaluasi proses memecahkan masalah (evaluasi dan mengambil kesimpulan dari penyelesaian).

\section{Kemampuan Koneksi Matematis}

Koneksi matematika merupakan dua kata yang berasal dari Mathematical Connection yang dipopulerkan oleh NCTM (National Council of Teacher of Mathematics) dan dijadikan sebagai standar kurikulum pembelajaran matematika sekolah dasar dan menengah. Kemampuan koneksi matematis adalah kemampuan mengaitkan antartopik matematika, mengaitkan matematika dengan disiplin ilmu lain, dan mengaitkan matematika dengan kehidupan sehari-hari (Fajar, Wahyuni, \& Santi, 2019; Astuti, Hartono, Bunayati, \& Indaryanti, 2017; Lestari \& Yudhanegara, 2015).

Berdasarkan penjelasan di atas, dapat disimpulkan bahwa kemampuan koneksi matematis merupakan kemampuan peserta didik dalam mencari hubungan dari suatu konsep dan prosedur, kemudian memahami antar topik dalam matematika, dan kemampuan peserta didik mengaplikasikan konsep matematika tersebut ke dalam bidang lain atau dalam kehidupan sehari-hari dan mengaitkan antara topik dalam pelajaran matematika.

Menurut NCTM (2000), indikator untuk kemampuan koneksi matematis, yaitu (1) mengenali dan memanfaatkan hubungan-hubungan antara gagasan dalam matematika, (2) memahami bagaimana gagasan-gagasan dalam matematika saling berhubungan dan mendasari satu sama lain untuk menghasilkan suatu keutuhan koheren, dan (3) mengenali dan menerapkan matematika dalam konteks di luar matematika. Sejalan dengan hal tersebut, Lestari \& Yudhanegara (2015) mengemukakan indikator kemampuan koneksi matematis, yaitu (1) mencari hubungan berbagai representasi konsep dan prosedur, (2) memahami hubungan di 
antara topik matematika, (3) menerapkan matematika dalam bidang studi lain atau kehidupan sehari-hari, (4) memahami representasi ekuivalen suatu konsep, (5) mencari hubungan satu prosedur dengan prosedur lain dalam representasi yang ekuivalen, dan (6) menerapkan hubungan antartopik matematika dan antara topik matematika dengan topik di luar matematika.

Dalam penelitian ini, indikator koneksi matematika yang digunakan adalah (1) Mengenali dan menggunakan hubungan di anatara ide-ide matematika. dalam hal ini, peserta didik diharapkan dapat mengenali ide matematika dengan menuliskan apa yang diketahui, ditanyakan, serta konsep yang mendasari jawaban dan menggunakan ide matematika tersebut untuk menyelesaikan masalah. (2) Memahami bagaimana ide matematika terhubung dan menjadi satu kesatuan yang koheren. Dalam hal ini, peserta didik diharapkan untuk menyelesaikan masalah dari hubungan antara prosedur dengan konsep-konsep matematika yang mendasari jawaban dengan urutan langkah penyelesaian yang benar. (3) Mengenali dan mengaplikasikan matematika di bidang studi lain atau kehidupan sehari-hari. Dalam hal ini, peserta didik diharapkan dapat memodelkan masalah menjadi bentuk matematika dan menginterpretasikan jawaban ke dunia nyata.

\section{Hubungan Kemampuan Koneksi} Matematis dan Problem Based Learning (PBL)

Matematika tidak dapat dipisahkan dari konsep yang satu dengan konsep lainnya, maupun kaitan matematika dengan bidang ilmu yang lain ataupun kehidupan sehari-hari (Nurfauziyyah, Laelasari, \&
Maharani, 2018; Herawati, 2017). Kemampuan dasar yang dapat dikembangkan untuk melihat keterkaitan antar matematika itu sendiri maupun matematika dengan topik di luar matematika adalah kemampuan koneksi matematis. Sedangkan Problem Based Learning (PBL) menjaadi model pembelajaran yang berorientasi pada rancangan permasalahan untuk mengaktifkan peserta didik saar memperdalam pengetahuannya dan melihat keterkaitan antar konsep saat memecahkan masalah. Diharapkan kemampuan koneksi matematis peserta didik dapat dilatih menggunakan Problem Based Learning (PBL).

\section{METODE PENELITIAN}

\section{Jenis Penelitian}

Penelitian ini merupakan penelitian pengembangan (development research) tipe formative research yang bertujuan untuk mengembangkan Lembar Kerja Peserta Didik (LKPD) yang valid dan praktis, serta memliki efek potensial berbasis Problem Based Learning (PBL) untuk melatih kemampuan koneksi matematis peserta didik pada materi turunan kelas XI.

\section{Waktu dan Tempat Penelitian}

Penelitian ini dilaksanakan di Kelas XI MIPA 1 SMA Negeri 2 Palembang pada semester genap tahun pelajaran 2018/2019 yang dimulai dari 1-29 April 2019.

\section{Subjek Penelitian}

Subjek penelitian ini adalah peserta didik kelas XI MIPA 1 SMA Negeri 2 Palembang yang berjumlah sebanyak 36 orang, yaitu 17 peserta didik laki-laki dan 19 peserta didik perempuan. 


\section{Prosedur}

Prosedur pada penelitian ini dijabarkan sebagai berikut.

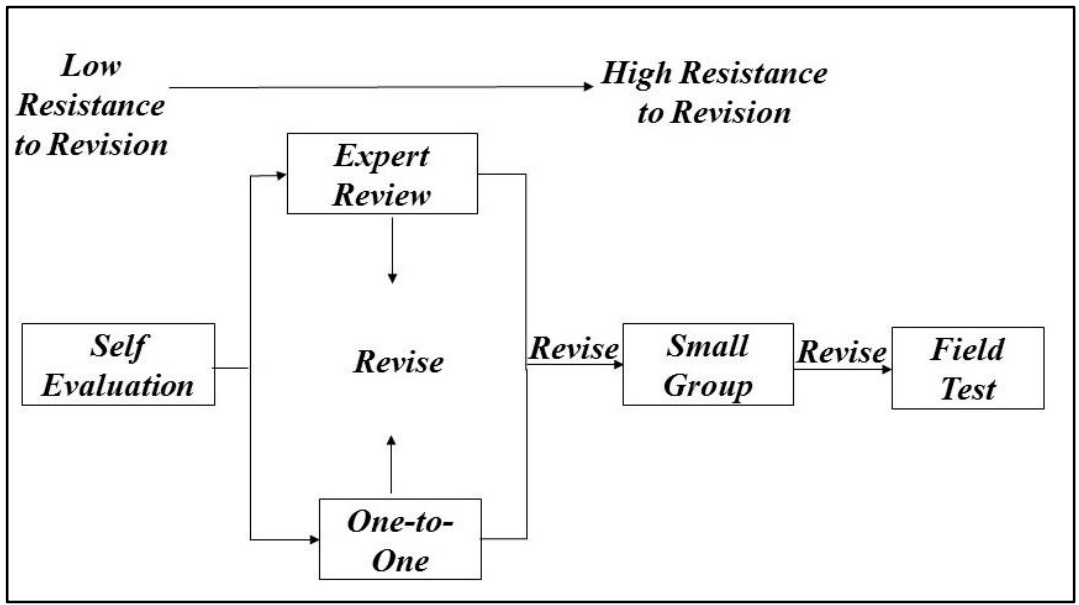

Gambar 1. Alur desain formative research (Tessmer, 1993; Zulkardi, 2002)

Berdasarkan alur desain formative research di atas, penelitian ini dibagi menjadi tiga tahap, yaitu self evaluation (tahap persiapan dan pendesainan), formative evaluation (expert review dan one-to-one, serta small group), kemudian field test.

Pada tahap self evaluation, peneliti menyusun instrumen penelitian yang terdiri dari Rencana Pelaksanaan Pembelajaran (RPP) dan Lembar Kerja Peserta Didik (LKPD) berbasis Problem Based Learning (PBL), dan soal tes untuk melihat kemampuan koneksi matematis peserta didik beserta rubrik penskoran. Pendesainan instrumen penelitian ini didasarkan pada tujuan pencapaian hasil belajar sesuai dengan Kurikulum 2013 revisi dan berbasis pada Problem Based Learning (PBL).

Selanjutnya pada tahap formative evaluation, instrumen penelitian divalidasi oleh 3 dosen pakar dan 2 guru mata pelajaran matematika. Validasi dilakukan dengan berpedoman pada indikator kemampuan koneksi dan langkah-langkah Problem Based Learning (PBL). Sejalan dengan itu, peneliti juga mengujicobakan instrumen penelitian ke beberapa peserta didik. Peneliti kemudian merevisi instrumen penelitian berdasarkan hasil diskusi validasi dan uji coba ke beberapa peserta didik.

Pada tahap field test, kegiatan penelitian dilakukan sesuai dengan kegiatan pembelajaran dalam RPP dan LKPD. Pada akhir pelaksanaan penelitian, peneliti mengambil data tes kemampuan koneksi matematis peserta didik pada materi turunan fungsi aljabar.

Data, Intrumen, dan Teknik Pengumpulan Data

Data yang dikumpulkan dalam penelitian ini adalah wawancara dan analisis dokumen dan tes. Wawancara yang dilakukan dalam penelitian ini adalah wawancara tak terstruktur yang digunakan berupa garis-garis besar permasalahan yang akan ditanyakan. Analisis dokumen untuk melihat kevalidan dan kepraktisan dilakukan terhadap RPP, LKPD, dan soal tes secara konten, konstruk, dan bahasa oleh pakar. Tes dilakukan untuk melihat efek potensial sejauh mana kemampuan koneksi peserta didik dengan menggunakan 
Problem Based Learning (PBL). Kemudian koneksi matematis peserta didik didapat dari tes akhir setelah selesai materi pembelajaran. Soal tes yang diberikan berbentuk uraian dan mengacu pada indikator koneksi matematis, yaitu : (1) mengidentifikasi hal-hal yang diketahui dan ditanyakan untuk menyelesaikan masalah kehidupan sehari-hari, (2) menuliskan masalah kehidupan sehari-hari menjadi bentuk matematika, dan (3) menggunakan hubungan antara materi prasyarat dengan masalah yang akan diselesaikan.

Soal tes yang dikerjakan peserta didik diperiksa sesuai dengan pedoman penskoran yang telah dibuat.

\section{Teknik Analisis Data}

Analisis pada penelitian ini dibagi menjadi dua, yaitu analisis dokumen dan analisis hasil tes, serta didukung wawancara tidak terstruktur. Analisis dokumen dilakukan untuk melihat kevalidan dan kepraktisan LKPD. Adapun kevalidan LKPD dianalisis dengan merevisi berdasarkan hasil diskusi dengan pakar dan hasil ujicoba ke beberapa peserta didik. Validasi oleh pakar dilakukan dengan mempertimbangkan Konten (LKPD sesuai dengan tujuan pembelajaran pada Kurikulum 2013 revisi), Konstruk (LKPD sesuai dengan Problem Based Learning dan mendukung indikator kemampuan koneksi matematis), dan Bahasa (LKPD sesuai dengan EYD dan intruksinya jelas).

Efek potensial terhadap kemampuan koneksi matematis peserta didik akan dianalisis berdasarkan hasil tes. Data tes diambil dari setiap langkah penyelesaian soal-soal yang diberikan. Setelah dilakukan tes untuk mengukur koneksi matematis peserta didik, didapatkanlah skor untuk masing-masing peserta didik. Skor yang didapat tersebut dijumlahkan dan kemudian dianalisis. Cara menganalisisnya adalah sebagai berikut.

1. Mengkonversikan skor dalam bentuk nilai. Skor yang telah diperoleh, dikonversikan menjadi nilai dalam rentang $0-100$ menggunakan aturan sebagai berikut.

$$
\text { Nilai }=\frac{\text { jumlah skor yang diperoleh }}{\text { skor maksimal }}
$$

2. Menentukan kategori kemampuan koneksi matematis peserta didik. Setelah nilai setiap peserta didik diperoleh, selanjutnya adalah menentukan kategori kemampuan koneksi matematis peserta didik yang dapat dilihat pada tabel 1 .

Tabel 1. Kategori kemampuan koneksi matematis peserta didik

\begin{tabular}{cl}
\hline Nilai Peserta Didik & \multicolumn{1}{c}{ Kategori } \\
\hline $91-100$ & Sangat Baik \\
$83-90$ & Baik \\
$75-82$ & Cukup \\
$0-75$ & Kurang \\
\hline
\end{tabular}

\section{HASIL PENELITIAN DAN PEMBAHASAN}

Penelitian ini bertujuan untuk menghasilkan Lembar Kerja Peserta Didik (LKPD) berbasis Problem Based Learning (PBL) yang valid dan praktis, serta untuk mengetahui efek potensial terhadap kemampuan koneksi matematis peserta didik pada materi turunan. Pada penelitian pengembangan LKPD ini melalui tahapan: self evaluation, formative evaluation, dan field test. 
Pada self evaluation, peneliti melakukan persiapan berupa mengurus perizinan penelitian ke sekolah yang dituju dan analisis tujuan pembelajaran sesuai Kurikulum 2013 revisi. Selanjutnya peneliti membuat desain awal instrumen penelitian berupa RPP, LKPD, soal tes dan rubrik penskoran. Kemudian pada tahap formative evaluation, peneliti melakukan evaluasi terhadap desain awal instrumen penelitian yang telah dibuat dengan melakukan self evaluation, expert review, dan one-to one. Hasil perbaikan desain awal dari tahapan ini dilanjutkan pada ujicoba ke small group. Dari ujicoba small group diperoleh beberapa perbaikan lagi terhadap desain sebelumnya untuk direvisi kembali, selanjutnya diujicobakan ke field test.

\section{Desain Lembar Kerja Peserta Didik Berbasis Problem Based Learning untuk Melatih Kemampuan Koneksi Matematis}

Peneliti mendesain LKPD berbasis Problem Based Learning (PBL) pada materi aplikasi turunan untuk 2 kali pertemuan proses pembelajaran dan 1 kali pertemuan untuk tes. Pertemuan pertama menyajikan permasalahan nilai optimum (nilai maksimum) suatu fungsi menggunakan turunan pertama, pertemuan kedua menjadikan permasalahan nilai optimum (nilai minimum) suatu fungsi menggunakan turunan pertama, dan pertemuan ketiga menyajikan tes untuk kemampuan koneksi matematis peserta didik. Desain awal instrumen penelitian yang dirancang peneliti divalidasi oleh pakar dan diujicobakan one-to-one. Adapun validator adalah dosen-dosen Pendidikan Matematika FKIP Universitas Sriwijaya Palembang, guru matematika SMA Srijaya Negara Palembang, guru matematika SMA Negeri 2 Palembang. Beberapa hal yang perlu diperbaiki dari hasil validasi dan uji coba tersebut diringkas pada tabel 2 .

Tabel 2. Komentar, saran, dan keputusan perbaikan

\begin{tabular}{|c|c|c|}
\hline Instumen & Temuan Validasi dan One-to-One & Perbaikan \\
\hline $\mathrm{RPP}$ & $\begin{array}{l}\text { - Gambaran kegiatan masih belum } \\
\text { terlihat jelas dan langkah-langkah } \\
\text { kerja pada LKPD harus dijelaskan } \\
\text { pada RPP secara rinci } \\
\text { - Sesuaikan dengan format yang ada } \\
\text { di sekolah K13 revisi }\end{array}$ & $\begin{array}{l}\text { - Memperbaiki dan mendetailkan } \\
\text { langkah-langkah kerja RPP dari } \\
\text { LKPD } \\
\text { - Memperbaiki format sesuai K13 } \\
\text { revisi }\end{array}$ \\
\hline LKPD & $\begin{array}{l}\text { - Gambar dalam permasalahan } \\
\text { harus jelas } \\
\text { - } \\
\text { - Perbaiki redaksi kalimat pada soal } \\
\text { mengaiki perintah dan pertanyaan } \\
\text { penyelesaian } \\
\text { - Sesuaikan setiap langkah kerja } \\
\text { pada LKPD dengan proses PBL } \\
\text { - Pertimbangkan perintah membuat } \\
\text { grafik dari fungsi yang terdapat } \\
\text { dalam LKPD }\end{array}$ & $\begin{array}{l}\text { - } \text { Memperbaiki gambar pada } \\
\text { permasalahan } \\
\text { - } \text { Memperbaiki redaksi kalimat } \\
\text { pada soal LKPD } \\
\text { - Memperbaiki pertanyaan- } \\
\text { pertanyaan menggiring langkah } \\
\text { penyelesaian } \\
\text { - Menyesuaikan langkah-langkah } \\
\text { LKPD sesuai dengan proses PBL } \\
\text { - Menghapus perintah atau langkah } \\
\text { membuat grafik fungsi }\end{array}$ \\
\hline Soal Tes & $\begin{array}{l}\text { Permasalahan dalam soal tes perlu } \\
\text { ditambahkan beberapa konsep } \\
\text { - Indikator masih terlalu umum, }\end{array}$ & $\begin{array}{l}\text { Memperbaiki soal tes dengan } \\
\text { menambahkan beberapa konsep } \\
\text { lain selain konsep yang sedang }\end{array}$ \\
\hline
\end{tabular}




\begin{tabular}{|c|c|c|}
\hline Instumen & Temuan Validasi dan One-to-One & Perbaikan \\
\hline & $\begin{array}{l}\text { harus difokuskan lagi supaya } \\
\text { berbeda dengan kemampuan } \\
\text { matematis lainnya } \\
\text { - Kurangi jumlah soal tes, sesuaikan } \\
\text { dengan waktu pengerjaan }\end{array}$ & $\begin{array}{l}\text { dipelajari } \\
\text { - Memperbaiki indikator yang } \\
\text { digunakan } \\
\text { - Menghilangkan satu soal tes, } \\
\text { sehingga terdapat dua soal tes }\end{array}$ \\
\hline
\end{tabular}

Setelah peneliti melakukan perbaikan pada RPP, LKPD, dan soal tes, selajutnya peneliti mengujicobakan LKPD dan soal tes pada peserta didik yang bukan subjek penelitian (Kelas XI MIPA 3 SMA Negeri 2 Palembang). Berikut merupakan salah satu desain awal LKPD tentang permasalahan nilai optimum (nilai maksimum) suatu fungsi menggunakan turunan pertama (Gambar 2) yang kemudian direvisi (Gambar 3 dan Gambar 4).

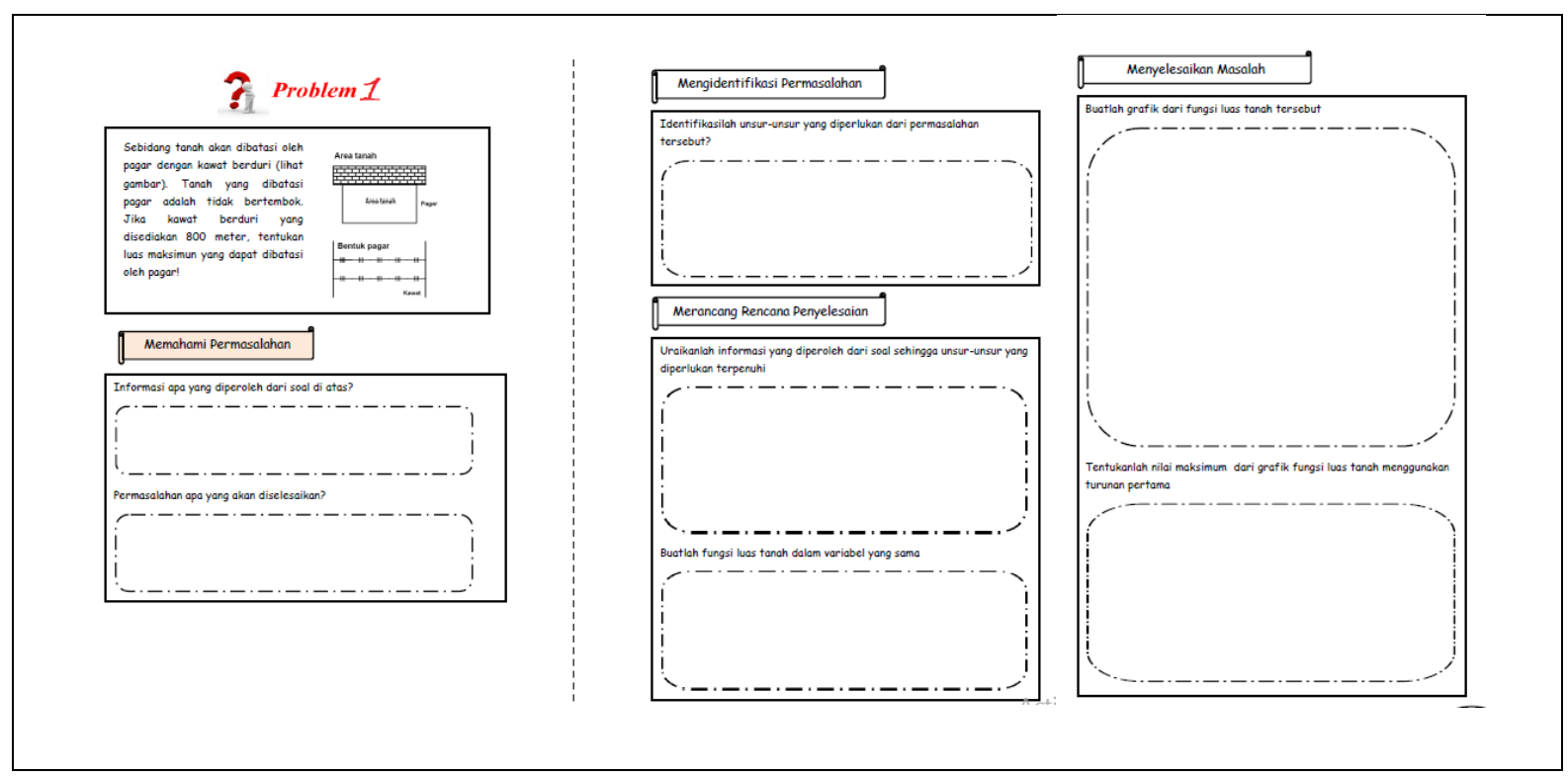

Gambar 2. LKPD prototype

Uji Coba Lapangan Lembar Kerja Peserta Didik Berbasis Problem Based Learning untuk Melatih Kemampuan Koneksi Matematis

LKPD dirancang sesuai dengan langkah-langkah Problem Based Learning (PBL), yaitu orientasi peserta didik pada masalah, mengorganisasikan peserta didik pada masalah, membimbing penyelidikan individu dan kelompok, mengembangkan dan menyajikan hasil karya, serta menganalisis dan mengevaluasi proses memecahkan masalah (Trianto, 2017:98).
Selain itu, LKPD dirancang untuk memunculkan kemampuan koneksi matematis peserta didik. Indikator pertama adalah mengidentifikasi hal-hal yang diketahui dan ditanyakan untuk menyelesaikan masalah kehidupan seharihari. Indikator kedua adalah menuliskan masalah kehidupan sehari-hari menjadi bentuk matematika. Indikator ketiga adalah menggunakan hubungan antara materi prasyarat dengan masalah yang akan diselesaikan. Berikut deskripsi proses pembelajaran pada pertemuan 1 . 
Pada pertemuan pertama, materi yang diajarkan adalah nilai optimum (nilai maksimum) suatu fungsi menggunakan turunan pertama. Kegiatan pembelajaran menggunakan LKPD sebagai media pembelajaran. Dalam kegiatan ini peserta didik dikelompokkan menjadi 9 kelompok belajar.

Peserta didik diberikan sebuah permasalahan di LKPD untuk menentukan luas maksimum suatu area tanah yang dapat dibatasi oleh pagar (Gambar 3). LKPD juga berisi beberapa pertanyaan sesuai dengan langkah-langkah PBL untuk materi nilai optimum (nilai maksimum) suatu fungsi menggunakan turunan pertama: orientasi peserta didik pada masalah (memahami permasalahan), mengorganisasikan peserta didik pada masalah (mengidentifikasi permasalahan), membimbing penyelidikan individu dan kelompok (merancang rencana penyelesaian), mengembangkan dan menyajikan hasil karya (mengembangkan rencana menyelesaikan) serta menganalisis dan mengevaluasi proses memecahkan masalah (evaluasi dan mengambil kesimpulan dari penyelesaian). Peneliti bertindak sebagai guru yang membimbing peserta didik dalam proses pembelajaran.
Dari pertemuan ini, peserta didik mulai memahami permasalahan dengan mampu mengenali ide-ide matematika dengan menuliskan apa yang diketahui dan ditanyakan. Kemudian mengidentifikasi unsur-unsur yang dibutuhkan dan mulai membuat ide/gagasan kelompknya dari masalah matematika yang dibuat. Berikut salah satu cuplikan dialog kelompok lima yang sedang berdiskusi meyelesaikan permasalahan di LKPD dan kegiatan kelompok dapat dilihat pada Gambar 3.

S1 : "diketahui panjang kawat $800 \mathrm{~m}$, dan bentuk pagarnya 2 rangkap."

S2 : "ini yang ditanya luas maksimum tanah yang dibatasi pagar, berarti butuh panjang dan lebar gambar ini."

S3 : "lihat dulu ini nah sebelah yang nempel tembok itu kan nggak dipagarin, itu bagian panjang. Terus gunakan keliling kan untuk cari panjang dan lebar tanah."

S4 : "karena ada yang nggak dipagarin, artinya kelilingnya panjangnya 1 yang dirangkap 2 kawat, dan lebarnya 2 yang dirangkap 2 kawat."

S1 : "jadi kelilingnya itu $2 p$ ditambah 4 lebar

\section{Problem 1}
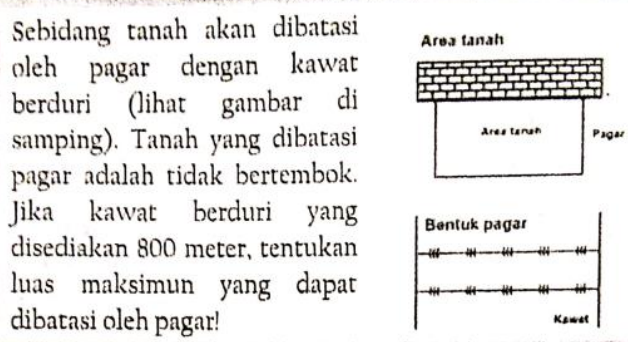

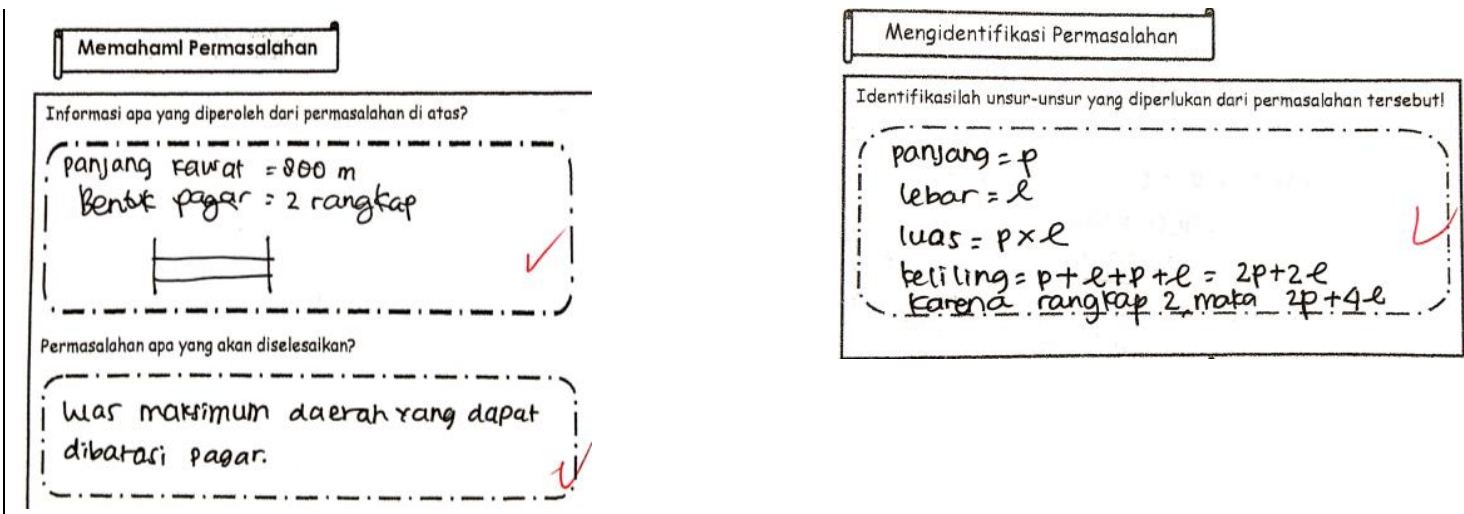

Gambar 3. Peserta didik memahami dan mengidentifikasi permasalahan (Kelompok 5)

Pada saat diskusi juga terlihat peserta didik mengidentifikasi dan merancang rencana penyelesaian masalah dengan membuat ide/ gagasan kelompoknya dari permasalahan matematika yang dibuat. Kemudian peserta didik diarahkan untuk membuat membentuk model matematika dan beberapa persamaan. Pada proses ini peserta didik masih perlu bimbingan untuk mengaitkan persamaan-persamaan tersebut untuk menyelesaikan permasalahan yang terdapat pada LKPD. Selanjutnya, peserta didik mengembangkan rencana penyelesaian dengan menentukan panjang dan lebar daerah yang dibatasi pagar menggunakan turunan pertama. Berikut ini cuplikan dialog kelompok empat dan kegiatan kelompok dapat dilihat pada Gambar 4.

M5 : "kita gunain keliling tadi kan, jadi $800=2 p+4 l . \quad$ Disederhanain jadi $400=p+2 l$.,
$P \quad:$ "terus setelah disederhanakan ini bagaimana untuk mengarah ke panjang dan lebar tadi?

M6 : "kalo kita mau buat bentuk l, berarti $l=\frac{400-p}{2}$. Kita subtitusi $l$ ini ke Luas $=p \times l$, bisa dapat fungsi bentuk $L=200 p-\frac{1}{2} p^{2}$.

M5 : "harusnya $L(p)$ ini. Nilai maksimumnya kalau turunan pertamanya $\left(L^{\prime}(p)\right)$ nya sama dengan no. Dapat $p=200$ dan $l=100 ”$

M7 : "aku cari luas maksimumnya, jadi $2000 \mathrm{~m}^{2}$.

Selanjutnya, peserta didik mulai merancang rencana penyelesaian dengan menguraikan informasi yang diperoleh untuk menyelesaikan permasalahan yang dapat dilihat pada Gambar 4. 


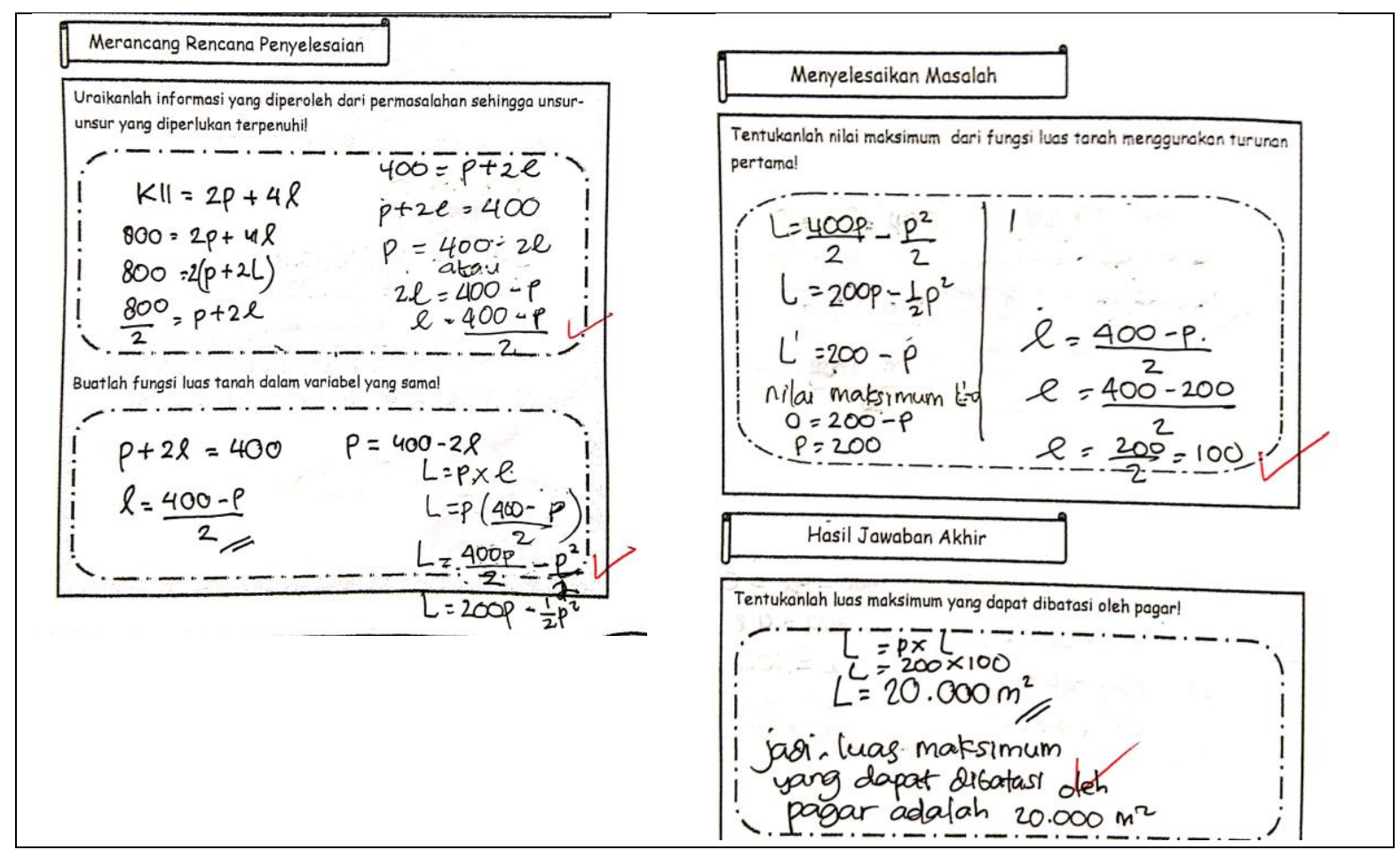

Gambar 4. Peserta didik merancang rencana penyelesaian dan menyelesaikannya

(Kelompok 4)

Dari pekerjaan peserta didik pada gambar 4, kelompok empat menggunakan turunan pertama dari fungsi yang digunakan untuk mencari panjang dan lebar tanah yang dibatasi oleh pagar, kemudian menghitung luas daerah itu menggunakan rumus luas persegi panjang.

Sedangkan pada kelompok 5 terdapat hal yang sedikit berbeda. Ketika merancang rencana penyelesaian peserta didik membuat persamaan dalam bentuk $p$ (panjang) untuk membuat fungsi $f(l)$. Berikut ini cuplikan dialog kelompok lima dan kegiatan kelompok dapat dilihat pada Gambar 5.
M8 : "kita buat persamaannya dalam $p$ saja ya, jadinya $p=200-2 l$. Jadi fungsinya itu $f(l)=(400-2 l) l$.

$P \quad$ : "terus kalo sudah dapat fungsi gimana?"

M9 : "berarti dari $f(l)=-2 l^{2}+400 l$ ini kita cari turunan pertama kan dengan pake kalo $f^{\prime}(l)=0$ jadi maksimum didapat $l=100$."

M8 : "cari luas maksimumnya subtitusi $l=100$ ini ke fungsi yang kita dapat tadi loh, berapa jadi?"

M9 : "20.000 jadinya”. 


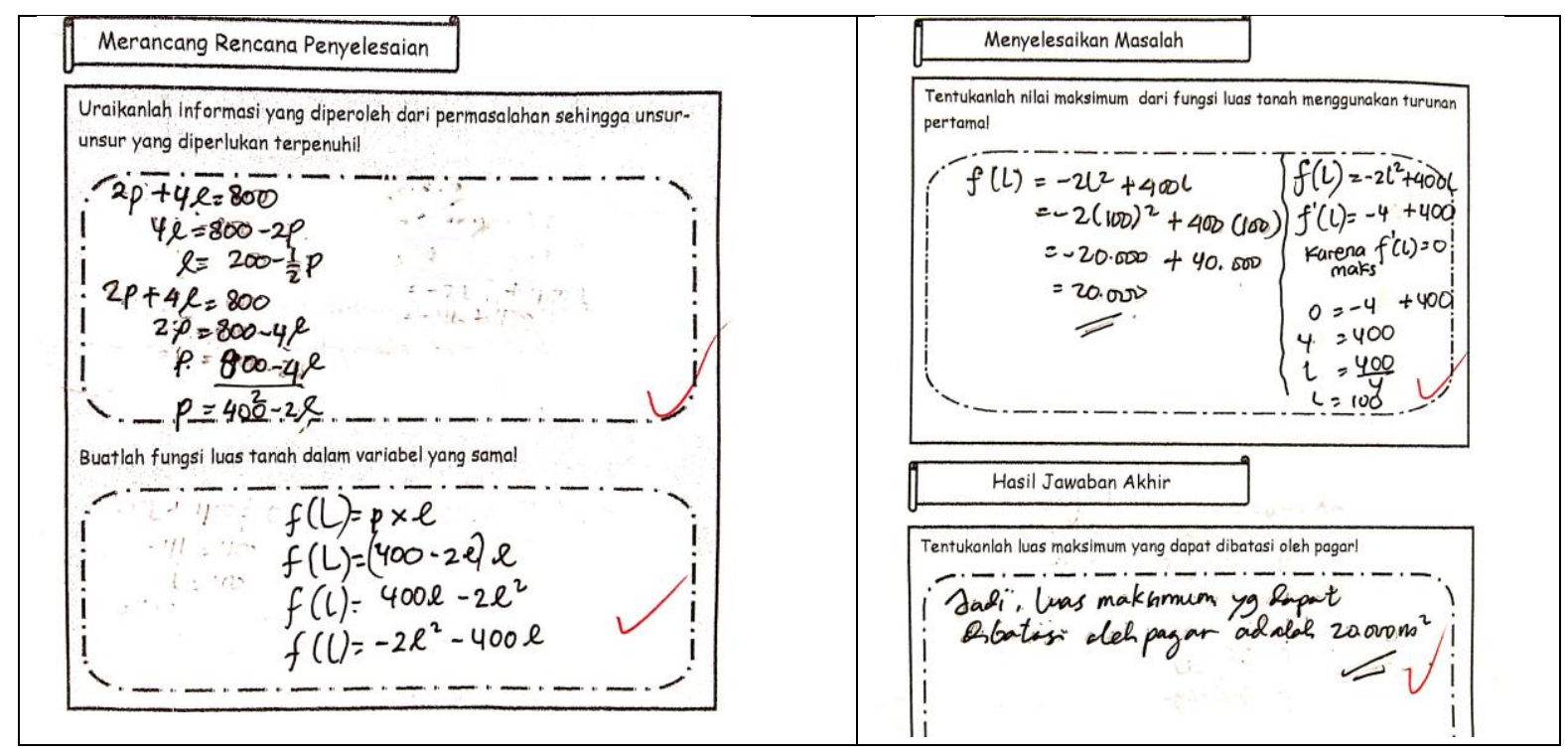

Gambar 5. Peserta didik merancang rencana penyelesaian dan menyelesaikannya

(Kelompok 5)

Dari pekerjaan peserta didik pada gambar 5, kelompok lima menggunakan turunan pertama dari fungsi aljabar yang digunakan untuk mencari lebar tanah yang dibatasi oleh pagar, kemudian menghitung luas daerah itu dengan mensubtitusi nilai lebar ke fungsi yang didapat.

Berdasarkan cuplikan-cuplikan di atas dan hasil presentasi kelompok di depan kelas, terlihat bahwa dengan sedikit arahan peneliti, peserta didik telah mampu menggunakan ide-ide matematika yang mereka kenali untuk menyelesaikan permasalahan yang terdapat pada LKPD. Dengan mengemukakan pendapat-pendapat yang berbeda tentu bertambah mantap dan luas pemahaman peserta didik untuk menyelesaikan permasalahan yang diberikan (Nurdiyanto, Hartono, \& Indaryanti, 2019).

Dari pertemuan ini dapat disimpulkan bahwa LKPD yang dirancang dengan langkah-langkah PBL telah dapat memunculkan indikator kemampuan koneksi matematis peserta didik. Namun, peserta didik masih perlu arahan dari peneliti yang berperan sebagai guru untuk mengaitkan beberapa persamaan untuk menyelesaikan permasalahan, serta mengingatkan kembali materi sebelumnya yang telah diperlajari yang berkaitan dengan permasalahan.

Kemampuan Koneksi Matematis pada Materi Turunan Berbasis Problem Based Learning

Pada pertemuan ketiga dilakukan evaluasi untuk melihat kemampuan koneksi matematis peserta didik setelah diterapkan media LKPD berbasis Problem Based Learning (PBL). Pada tes evaluasi diberikan 2 soal uraian. Soal tes yang telah dikerjakan peserta didik diperiksa dan diberikan nilai sesuai rubrik penilaian yang telah dibuat sesuai dengan indikator kemampuan koneksi matematis. Skor tersebut kemudian dikonversikan ke dalam bentuk nilai. Selanjutnya diperiksa hasil jawaban peserta didik dengan menggunakan indikator kemampuan koneksi matematis. Adapun kemampuan koneksi matematis peserta didik yang telah dianalisis dan dikonversikan sesuai aturan, dapat dilihat pada tabel 3 dan tabel 4 berikut. 
Tabel 3. Distribusi frekuensi kemampuan koneksi matematis peserta didik

\begin{tabular}{clcc}
\hline \multirow{2}{*}{ Nilai } & \multirow{2}{*}{ Kategori } & \multicolumn{2}{c}{ Kemampuan Koneksi Matematis Peserta } \\
& & Frekuensi & didik \\
\cline { 3 - 4 } & & 4 & $11,11 \%$ \\
$91-100$ & Sangat Baik & 16 & $44,44 \%$ \\
$83-90$ & Baik & 14 & $38,89 \%$ \\
$75-82$ & Cukup & 2 & $5,56 \%$ \\
$0-75$ & Kurang & & $\mathbf{8 4 , 9 7}$
\end{tabular}

Tabel 4. Persentase kemampuan koneksi matematis berdasarkan indikator

\begin{tabular}{clc}
\hline No & \multicolumn{1}{c}{ Indikator } & Persentase \\
\hline 1 & $\begin{array}{l}\text { Mengenali dan menggunakan hubungan antar ide-ide dalam } \\
\text { matematika }\end{array}$ & $94,44 \%$ \\
2 & $\begin{array}{l}\text { Keterkaitan ide-ide matematika dan membentuk ide satu } \\
\text { kesatuan yang koheren }\end{array}$ & $86,11 \%$ \\
3 & $\begin{array}{l}\text { Mengenali dan mengaplikasikan di bidang studi lain atau } \\
\text { kehidupan sehari-hari }\end{array}$ & $72,22 \%$ \\
\hline
\end{tabular}

Tabel 4 menunjukkan bahwa kemampuan koneksi matematis peserta didik terkategori baik dengan rata-rata 84,97. Sedangkan tabel 5 memperlihatkan persentase kemunculan indikator-indikator kemampuan koneksi matematis. Dari tabel 5 terlihat bahwa persentase kemunculan indikator paling tinggi adalah indikator pertama, yaitu mengenali dan menggunakan hubungan antar ide-ide

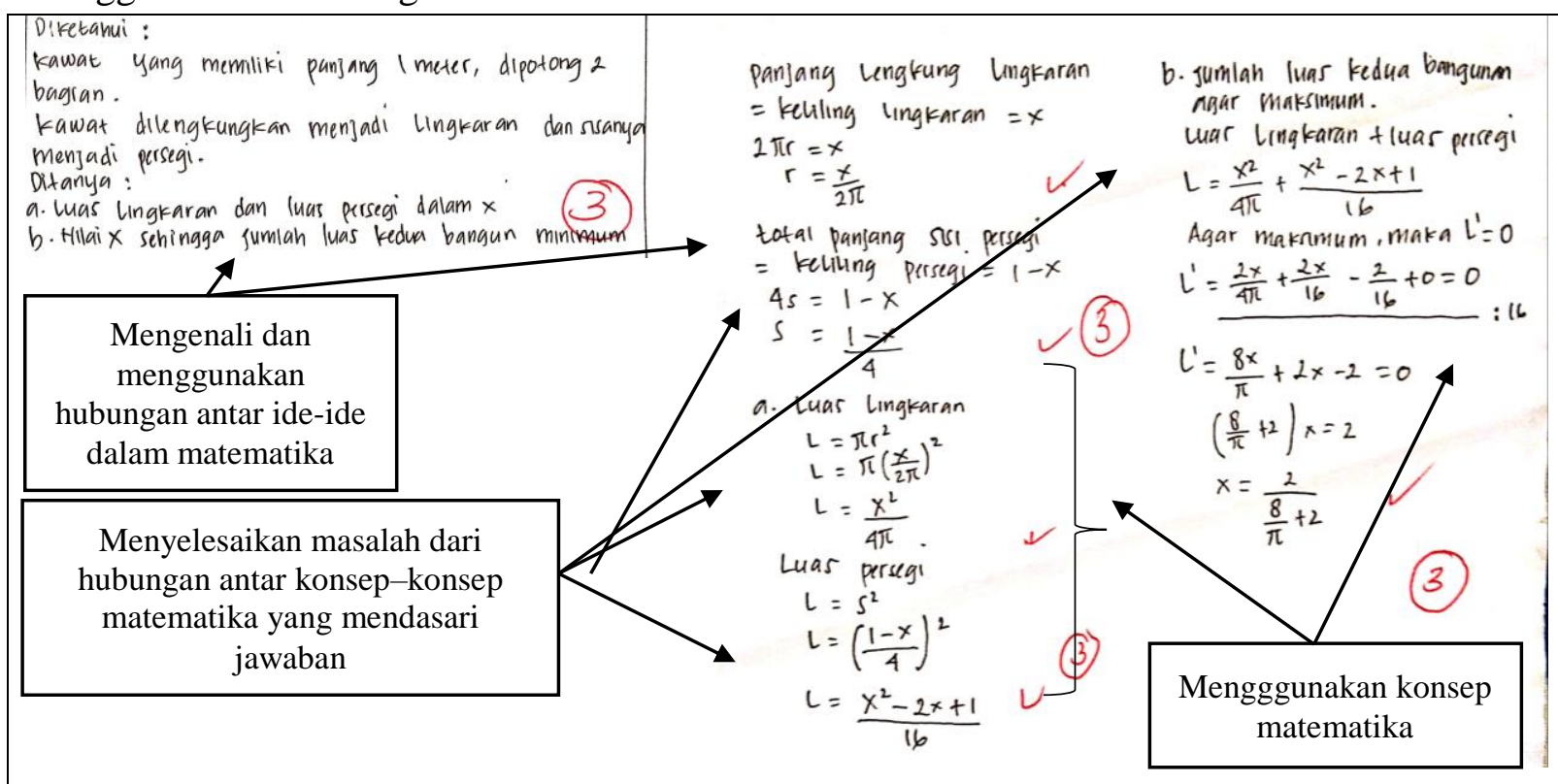

Gambar 6. Pekerjaan NAFD jawaban soal nomor 1 
Lembar jawaban di atas (Gambar 6) merupakan jawaban untuk soal nomor 1 . Ketiga indikator kemampuan koneksi matematis sudah muncul. Mulai dari indikator mengenali dan menggunakan antar ide-ide dalam matematis sudah terlihat dari jawaban peserta didik tersebut dengan menuliskan kembali apa yang diketahui dan ditanya serta menggunakan konsep-konsep matematis yang mendasari jawaban. Peserta didik juga telah melakukan indikator memanfaatkan keterkaitan ide-ide matematika dan membentuk ide satu dengan ide yang lainnya dengan menuliskan urutan langkaah-langkah penyelesaian yang digunakan dengan tepat. Berikut cuplikan dialog wawancara peneliti dan peserta didik.

$P \quad$ : "informasi apa yang didapat dari permasalahan ini?"

NAFD : "kawat ini dibagi 2, satunya berbentuk lingkaran dan satunya berbentuk persegi. Panjang kawat dalam lengkung lingkaran yang merupakan keliling lingkaran kita misalkan $x$, maka dengan rumus keliling lingkaran didapatkan $r=$ $\frac{x}{2 \pi}$.

$P \quad$ : "kemudian untuk yang persegi?"

$N A F D$ : "yang persegi jadi $1-x$ keliling persegi. Jadinya dengan gunakan rumus keliling persegi jadinya $4 s=1-x$. Baru kemudian uat persamaan dengan gunakan luas lingkaran dan luas persegi."

$P \quad$ : "bagaimana NAFD mencari nilai $x$ agar jumlah luas kedua bangun agar maksimum?"

NAFD : "karena jumlah maka luas lingkaran ditambah luas persegi, sehingga di dapat persamaan ini (menunjuk persamaan). Nah, agar maksimum maka $L^{\prime}=0$, sehingga setelah dihitung dapatlah $x=\frac{2}{\frac{8}{\mu}+2}$.

Dari hasil tes dan wawancara, peneliti berpendapat bahwa kemampuan koneksi matematis NAFD terkategori baik. 


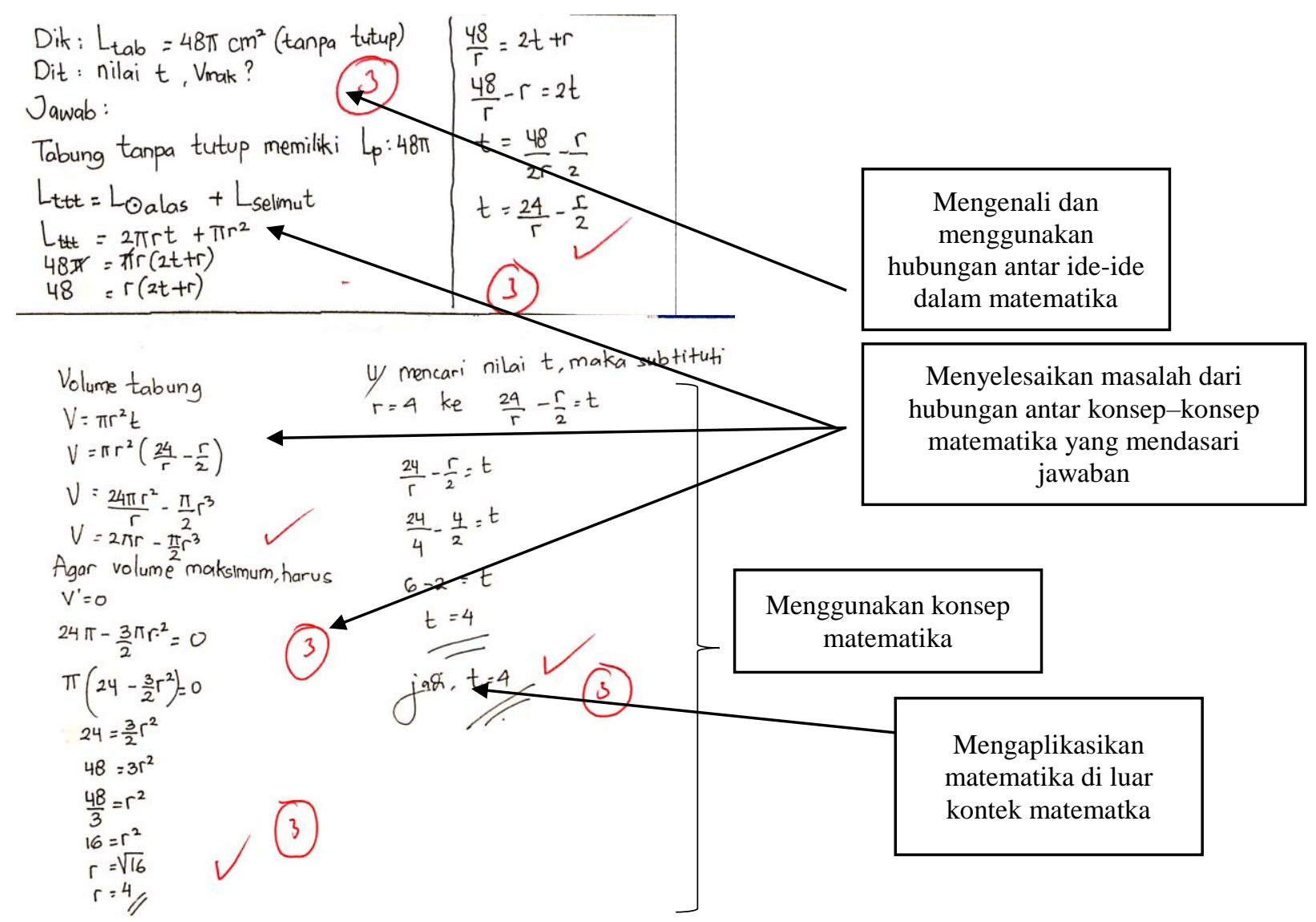

Gambar 7. Pekerjaan AV jawaban soal nomor 2

Lembar jawaban di atas (Gambar 7) merupakan jawaban untuk soal nomor 2 . Ketiga indikator kemampuan koneksi matematis sudah muncul pada jawaban. Peserta didik mengenali dan menggunakan antar ide-ide dalam matematis dengan menuliskan kembali apa yang diketahui dan ditanya serta menggunakan konsep-konsep matematis yang mendasari jawaban. Kemudian peserta didik memanfaatkan keterkaitan ide-ide matematika dan membentuk ide satu dengan ide yang lainnya dengan menuliskan urutan langkahlangkah penyelesaian yang digunakan dengan tepat. Setelah itu, peserta didik mengaplikasikan matematika di luar konteks matematika. Berikut cuplikan dialog wawancara peneliti dan peserta didik.
$P \quad$ : "informasi apa yang diperoleh dari permasalahan ini AV?"

$A V$ : " luas permukaannya $48 \pi \mathrm{cm}^{2}$ tapi tanpa tutup. Nah kalo volumenya maksimum, kita diminta mencari tinggi wadah."

$P \quad$ : "jadi gunakan konsep apa saja?"

$A V \quad$ : "gunakan luas permukaan tabung tapi tanpa tutup dan volume tabung ini. Nah jadi luas alas ditambah luas selimut., sehingga di dapat persamaan $t=\frac{24}{r}-\frac{r}{2}$. Kemudian persamaan ini kita subtitusi ke volume tabung."

$P \quad: \quad$ "kemudian agar volumenya maksimum bagaimana?"

$A V \quad:$ "berarti $V^{\prime}=0$ dan di dapatlah jari-jarinya 4. Nah jari-jari ini kita subtitusi ke persamaan awal tadi $t=\frac{24}{r}-$ 
$\frac{r}{2}$ didapatkan $t=4$ agar volumenya maksimum."

Dari hasil tes dan wawancara, peneliti berpendapat bahwa kemampuan koneksi matematis AV sangat baik.

\section{SIMPULAN DAN SARAN}

Berdasarkan hasil analisis, penelitian ini menghasilkan Lembar Kerja Peserta Didik (LKPD) yang valid dan praktis, serta memiliki efek potensial berbasis Problem Based Learning untuk melatih kemampuan koneksi matematis peserta didik pada materi turunan kelas XI. Valid tergambar dari penilaian validator dari segi konten, konstruk, dan bahasa. Sedangkan kepraktisan tergambar dari hasi ujicoba bahwa peserta didik dapat mengikuti langkah-langkah kegiatan di LKPD. Secara keseluruhan peserta didik dapat memahami serta menyelesaikan permasalahan yang diberikan guna menuntut koneksi matematis peserta didik pada materi turunan. LKPD memilik efek potensial yang terlihat dari hasil tes kemampuan koneksi matematis peserta didik kelas XI MIPA 1 SMA Negeri 2 Palembang terdapat empat kategori, yaitu peserta didik dengan kemampuan koneksi sangat baik $11,11 \%$, baik $44,44 \%$, cukup $38,89 \%$, dan kurang $5,56 \%$. Indikator kemampuan koneksi matematis yang paling tinggi muncul pada peserta didik, yaitu indikator pertama: mengenali dan menggunakan hubungan antar ide-ide dalam matematika sebesar 94,44\%, indikator kedua keterkaitan ide-de matematika dan membentuk ide satu sama kesatuan yang koheren sebesar $86,11 \%$, dan kemunculan indikator paling rendah adalah indikator ketiga mengenali dan mengaplikasikan matematika di bidang studi lain atau kehidupan sehari-hari sebesar $72,22 \%$

\section{DAFTAR PUSTAKA}

Apriliyanto, B. (2019). Analisis kesalahan siswa dalam pemecahan masalah turunan fungsi aljabar. Jurnal Komunikasi Pendidikan, 3(2), 117-125.

Asih, K.S., Rosita, C.D., \& Tonah. (2018). Analisis learning obstacles pada pokok bahasan aplikasi turunan pada siswa kelas XI SMA. Prosiding SNMPN II, Prodi Pendidikan Matematika, Unswagati, Cirebon. (pp. 211-221).

Astuti, P., Hartono, Y., Bunayati, H., \& Indaryanti. (2017). Pengembangan LKS berbasis pendekatan pemodelan matematika untuk melatih kemampuan koneksi matematis siswa SMP kelas VIII. Jurnal Pendidikan Matematika, 11(2), 61-77.

Atiningsih, S.M. (2018). Penerapan model problem based learning untuk meningkatkan tanggung jawab dan kemampuan koneksi matematika peserta didik kelas XI. Journal of Medives, 2(1), 77-86.

Burhanuddin, AG., \& Utami, T.P. (2017). Ketuntasan belajar turunan fungsi aljabar melalui pembelajaran think pair share. Serambi Academica, 5(2), 67-73

Fajar, D.S., Wahyuni, I., \& Santi, D.P.D. (2019). Desain bahan ajar berbasis kemampuan koneksi matematis siswa SMP pada kelas VII. JES-MAT, 5(2), 125-136.

Faudziah, L., Nurainah, Nuryatin, S., Maryanasari, R., \& Hidayat, W. (2019). Analisis kesulitan kemampuan koneksi matematis dilihat dari perbedaan jurusan di SMK. Journal On Education, 1(3), 101-106.

Herawati, L. (2017). Peningkatan kemampuan koneksi matematik peserta didik menggunakan model problem based learning (pbl) dengan berbantuan software geogebra. Jurnal Penelitian 
Pendidikan dan Pengajaran Matematika, 3(1), 39-44.

Kemendikbud. (2016). Peraturan menteri pendidikan dan kebudayaan nomor 20 tahun 2016 tentang standar kompetensi lulusan. Jakarta: Kemendikbud.

Kemendikbud. (2017). Silabus mata pelajaran matematika SMA /MA /SMK /MAK. Jakarta: Kemendikbud.

Lestari, K.A., \& Yudhanegara, M.R. (2015). Penelitian pendidikan matematika. Bandung: Refika Aditama.

Lestari, P., Saputri, S.A., \& Prihartini, E. (2016). Penerapan pembelajaran berbasis masalah untuk meningkatkan kemampuan koneksi matematis siswa sekolah menengah. PRISMA, Prosiding Seminar Nasional Matematika. (pp. 6571).

NCTM. (2000). Principle and standards for school mathematics. USA: NCTM.

Nurdiyanto, T., Rafida, I., \& Zulkardi. (2019). Pengembangan LKPD materi trigonometri berbasis generative learning di kelas X. Jurnal Pendidikan Matematika, 14(1), 51-66.

Nurdiyanto, T., Rafida, I., \& Zulkardi. (2019). Penerapan model generative learning untuk meningkatkan hasil belajar peserta didik pada materi limit kelas XI MIPA 1 SMA negeri 2 palembang. Lentera Sriwijaya: Jurnal Ilmiah Pendidikan Matematika, 1(1), 38-54.

Nurfauziyyah, F., Laelasari, \& Maharani, A. (2018). Desain bahan ajar berbasis kemampuan koneksi matematis dengan metode discovery learning. UJMES, 2(2), 155-59.

Prisiska, R.N., Hapizah, \& Yusuf, M. (2017). Pengembangan LKS berbasis problem based learning materi aritmatika sosiala kelas VII. JPPM, 10(2), 82-94.

Rusman. (2016). Model-model pembelajaran mengembangkan profesionalisme guru. Jakarta: Rajawali Pers.

Rustina, R., \& Anisa, W.N. (2018). Kontribusi model problem based learning terhadap peningkatan kemampuan koneksi dan pemecahan masalah matematik. Jurnal Riset Pendidikan Matematika Jakarta, 1(1), 8-14.

Septian, A., \& Komala, E. (2019). Kemmapuan koneksi matematik dan motivasi belajar siswa dengan menggunakan model problem-based learning (pbl) berbantuan geogebra di SMP. PRISMA, 8(1), 1-13.

Suprihatiningrum, J. (2014). Strategi pembelajaran: teori dan aplikasi. Yogyakarta: Ar-Ruzz Media.

Tessmer, M. (1993). Planning and conducting formative evaluations. London: Kogan Page.

Trianto. (2017). Mendesian model pembelajaran inovatif, progresif, dan kontekstual. Jakarta: Kencana Prenada Media Group.

Zulfah, Fauzan, A., \& Armiati. (2018). Pengembangan lembar kerja peseta didik berbasis problem based learning untuk materi matematika kelas VIII. Jurnal Pendidikan Matematika, 12(2), 33-46.

Zulkardi. (2002). Developning a learning environment on realistic mathematics education for Indonesian students teachers. Disertasi. Diakses tanggal 18 Januari 2019 dari http://project.edte.utwente.nl/cascade/i $\mathrm{mei} /$ dissertation/html. 